Helgoländer wiss. Meeresunters. 25, 1-13 (1973)

\title{
Codiolophyceae, a new class of Chlorophyta
}

\author{
P. KORNMANN \\ Biologische Anstalt Helgoland (Meeresstation); \\ Helgoland, Federal Republic of Germany
}

KURZFASSUNG: Codiolophyceaen, eine neue Grünalgen-Klasse. RouND (1971) gliedert die Chlorophyta in die Klassen der Zygnemaphyceae, Oedogoniophyceae, Bryopsidophyceae und Chlorophyceae. Ihnẹ füge ich als weitere Klasse die Codiolophyceae zu. Sie vereinigt Formen mit heteromorphem Generationswechsel; ihr Sporophyt ist das einzellige Codiolum-Stadium. $\mathrm{Zu}$ der neuen Klasse gehören die Ulotrichales, Monostromatales, Codiolales und Acrosiphoniales. Die Morphologie der Gametophyten zeigt eigene kennzeichnende Merkmale; sie trennen diese Ordnungen untereinander ebenso wie von allen anderen Grünalgengruppen. Gemeinsames Merkmal ist nicht nur das Vorhandensein des einzelligen Sporophyten, sondern auch dessen völlig übereinstimmende Entwicklung. Bisher waren die Vertreter der obigen Ordnungen in den verschiedensten Gruppen des Systems untergebracht, wo sie als Fremdkörper empfunden werden müssen. In der Zusammenfassung zu einer Klasse stellen sie dagegen eine wohlbegründete systematische Einheit dar.

\section{INTRODUCTION}

Just at the time when the article of Round (1971) on "The Taxonomy of the Chlorophyta. II" was published, I presented details of my previously suggested (KORNMANN 1970) concept of the new class of Codiolophyceae in Hamburg. As taxonomic problems and literature have been extensively discussed by Round, I am restricting this contribution to my own observations from culture work and consider it as an addition to Round's paper.

Some years ago, $I$ referred to the importance of the Codiolum sporophyte as a fundamental character for the classification of some groups of green algae (KoRNMANN 1963, 1965a). At that time, I also tried to find morphological similarities in the gametophytic phase, supporting the union of Ulotrichaceae, Monostromataceae and Codiolaceae in the order of the Ulotrichales. Acrosipbonia and Spongomorpha, though also possessing a Codiolum-stage, were considered as outsiders on account of the deviating habit of their branched gametophytes.

In the meantime, continued studies on the growth and development of these groups have led me to realize that general morphology of gametophytes is not suitable to indicate the relationships under consideration. The central position is really held by the Codiolum-stage, not only by reason of its existence, but chiefly by the agreement of its ontogenetic development in all the different genera. Early sporophyte stages of 
Monostroma, Gomontia, Ulotbrix, Spongomorpha and Acrosiphonia are practically identical; unfortunately, it was not possible to include primary stages of Hormiscia in the experiments, as sexual filaments are rarely found at Helgoland. On the other hand, each gametophyte of the above-mentioned genera has its own well-defined morphological characteristic, and they appear to have no fundamental similarities to each other nor to any other group of green algae.

In the system just proposed by Round (1971), the Chlorophyta include Zygnemaphyceae, Oedogoniophyceae, Bryopsidophyceae and Chlorophyceae. I now add the new class of Codiolophyceae. During the last few years, peculiarities in the ontogenetic development of their heteromorphic generations have been studied on the basis of culture work. A few examples of these will now be discussed.

\section{OBSERVATIONS}

\section{Monostroma grevillei}

Details extending former information on the life history of this species (KorNMANN 1962) are shown in the observation of primary developmental stages using a LEITZ immersion-objective $50 \times$. At $15^{\circ} \mathrm{C}$, germination of the zygote begins immediately after settlement (Fig. 1). Within five hours, a short hyaline germ tube is produced by the zygote, and $21 / 2$ hours later, its contents move into this protuberance. The process is complete four hours later: the young germlings have obtained the Codiolumhabit, a small green club on its stipe which is attached to the substratum by an extremely fine disk. Up to an age of two to three weeks, there are no changes in this structure apart from growth in size of club and stipe, then an exit tube for zoospore release is initiated (Fig. 2, 14.3.). It always grows out from the base of the sporophyte cell next to and parallel to the stalk. The exit tube is a supplementary organ restricted to shell-inhabiting sporophytes, and is absent in similar, but non-shell inhabiting Codiolum-stages of other species and genera.

Primary stages of the gametophyte develop from the zoospore in a characteristic and unique manner. In Figure 3, developmental stages are shown at daily intervals. The day after settlement, the zoospore has produced one elongated cell which has divided into two by the following day. At the same time, a second cell has grown out from the original zoospore. By the third day, the first outgrowth has branched laterally, the second has become two-celled and a new one has been produced by the central zoospore. Thus, within 5 days, five laterally branching systems, radiating from the zoospore, form a small monostromatic disk. This rapid growth takes place at a temperature of $15^{\circ} \mathrm{C}$. Then cultures must be transferred into lower temperature for further "normal" development. At 5-6 $6^{\circ} \mathrm{C}$, monostromatic grow th continues, the disk growing larger and at the same time forming a central upwelling which becomes the well known spherical and later elongated monostromatic sack of the young gametophyte (Fig. 4).

Typical Monostroma-species as $M$. bullosum (Kornmann 1964), M. grevillei (Kornmann 1962) and $M$. arcticum (Kornmann \& SahLing 1962) follow this pattern of blade development; others, such as M. undulatum (KornmanN \& SaHLing 1962) 
and M. latissimum, lack this spherical stage. (Life history and systematics in Monostroma have recently been summarized by TATEWAKI 1972.) Nevertheless, their heteromorphic life cycle speaks for their incorporation in the Monostromataceae, whereas
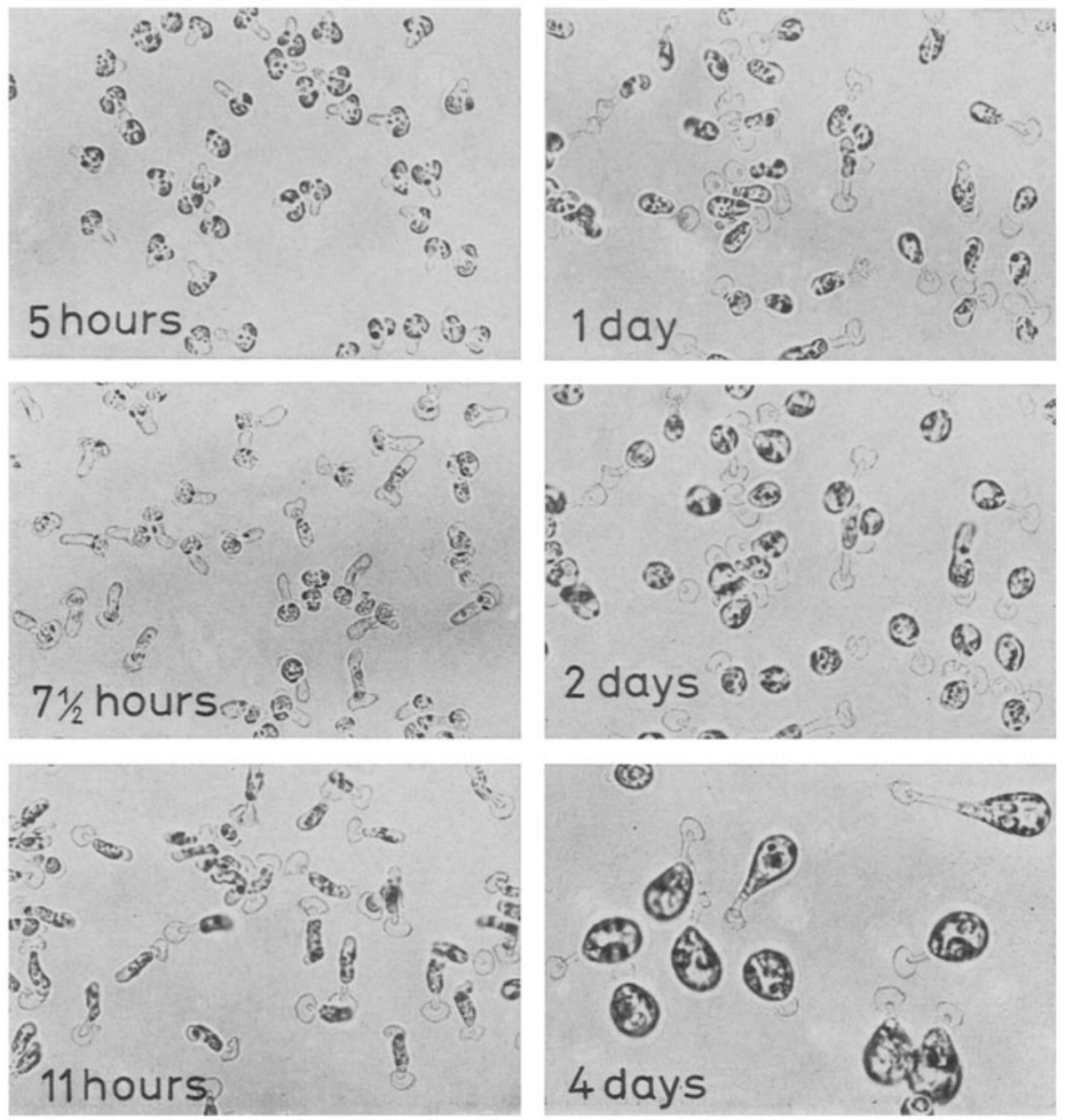

Fig. 1: Monostroma grevillei. Sporophyte development up to four days old. For further explanation see text

M. fuscum, M. oxyspermum and $M$. leptodermum have been transferred to genera of the Ulvaceae (BLIDING 1968). This family of Chlorophyceae is characterized by an isomorphic life cycle and a different kind of ontogeny.

On account of the leafy thallus I prefer the separation of the family Monostromataceae from the Ulotrichales formerly suggested (KoRNMANN 1965a) and its elevation to the rank of an order, the Monostromatales. 


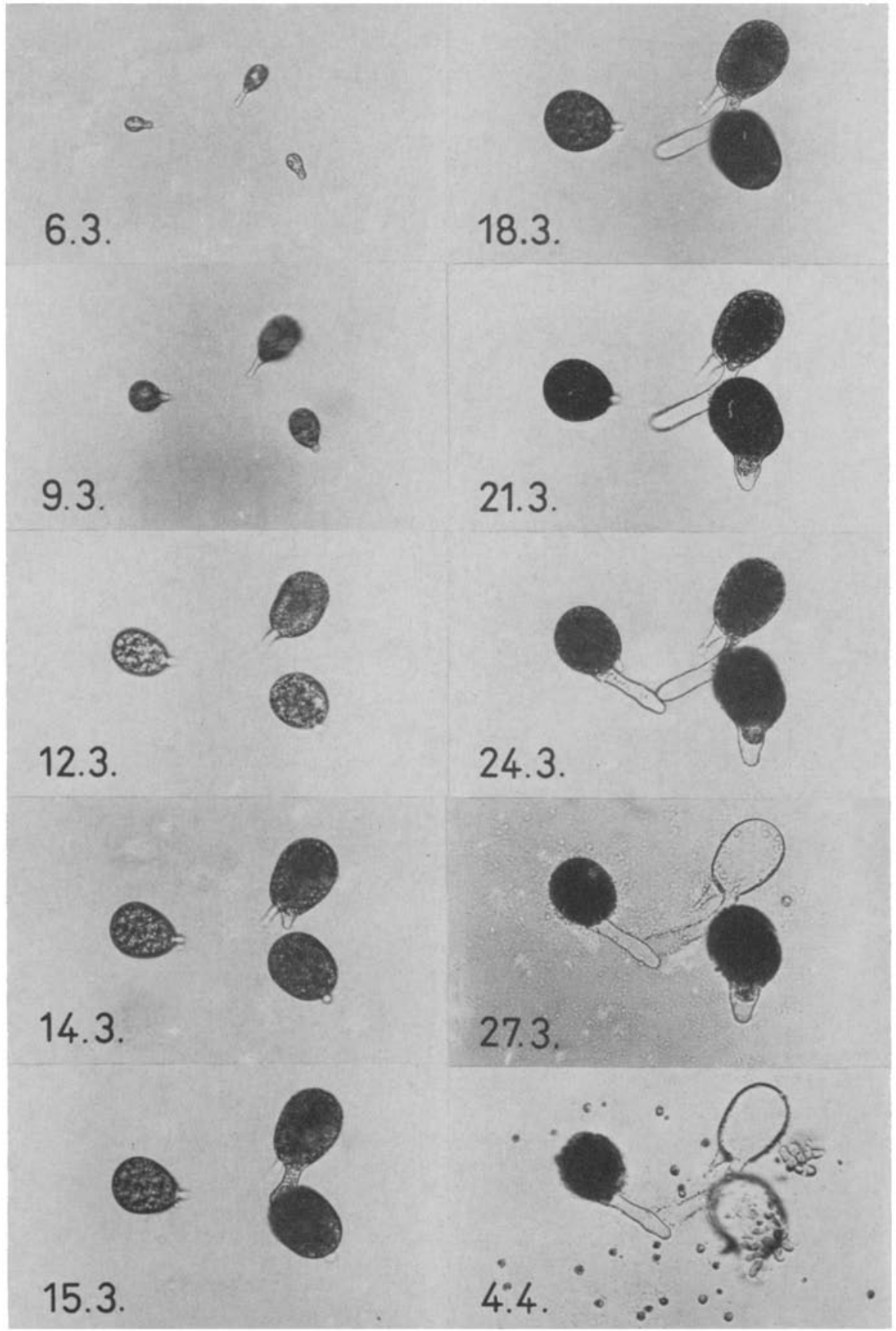

Fig. 2: Monostroma grevillei. Group of 6-day-old sporophytes, which became fertile wit. one month 


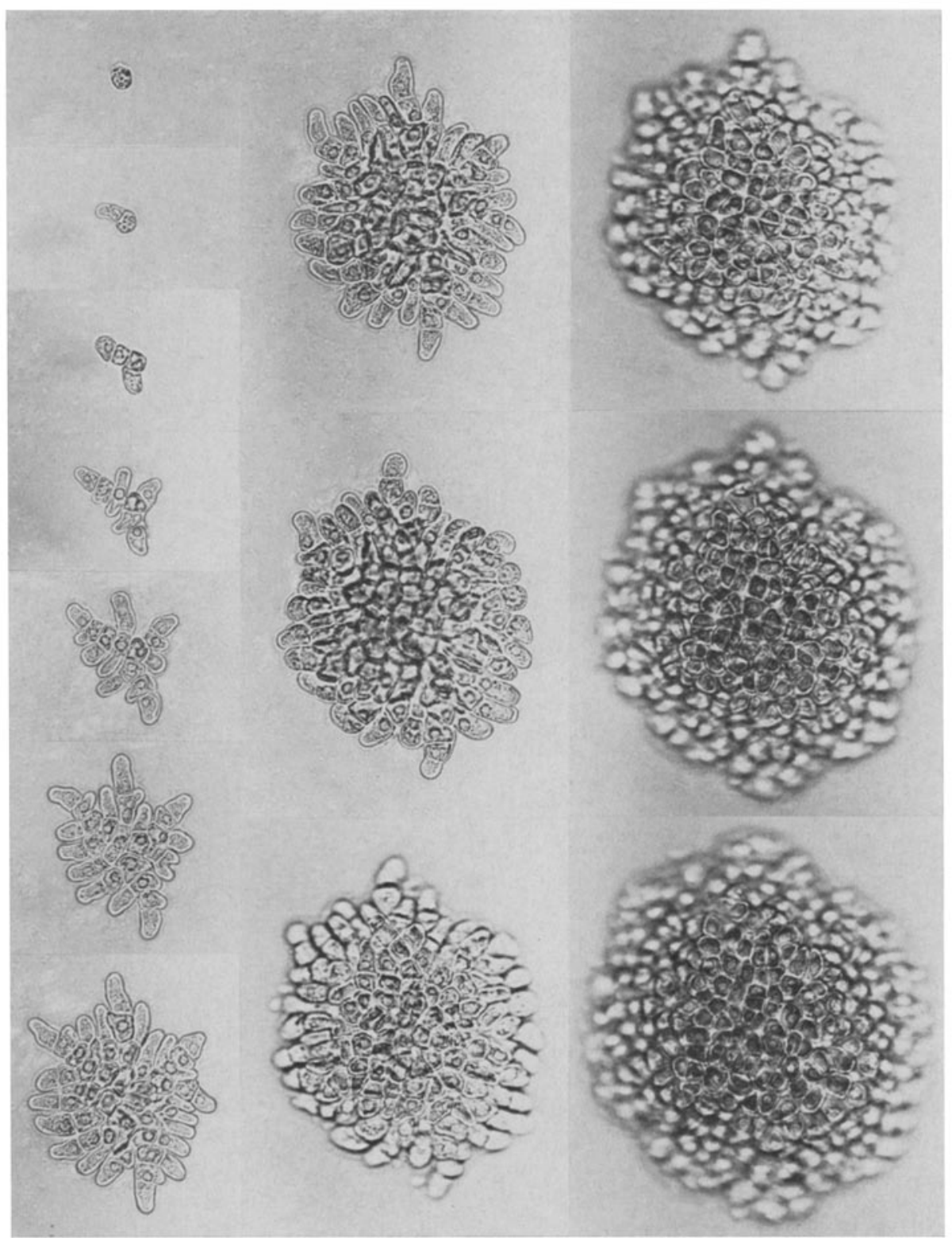

Fig. 3: Monostroma grevillei. Gametophyte development at daily intervals. For further explanation consult text 


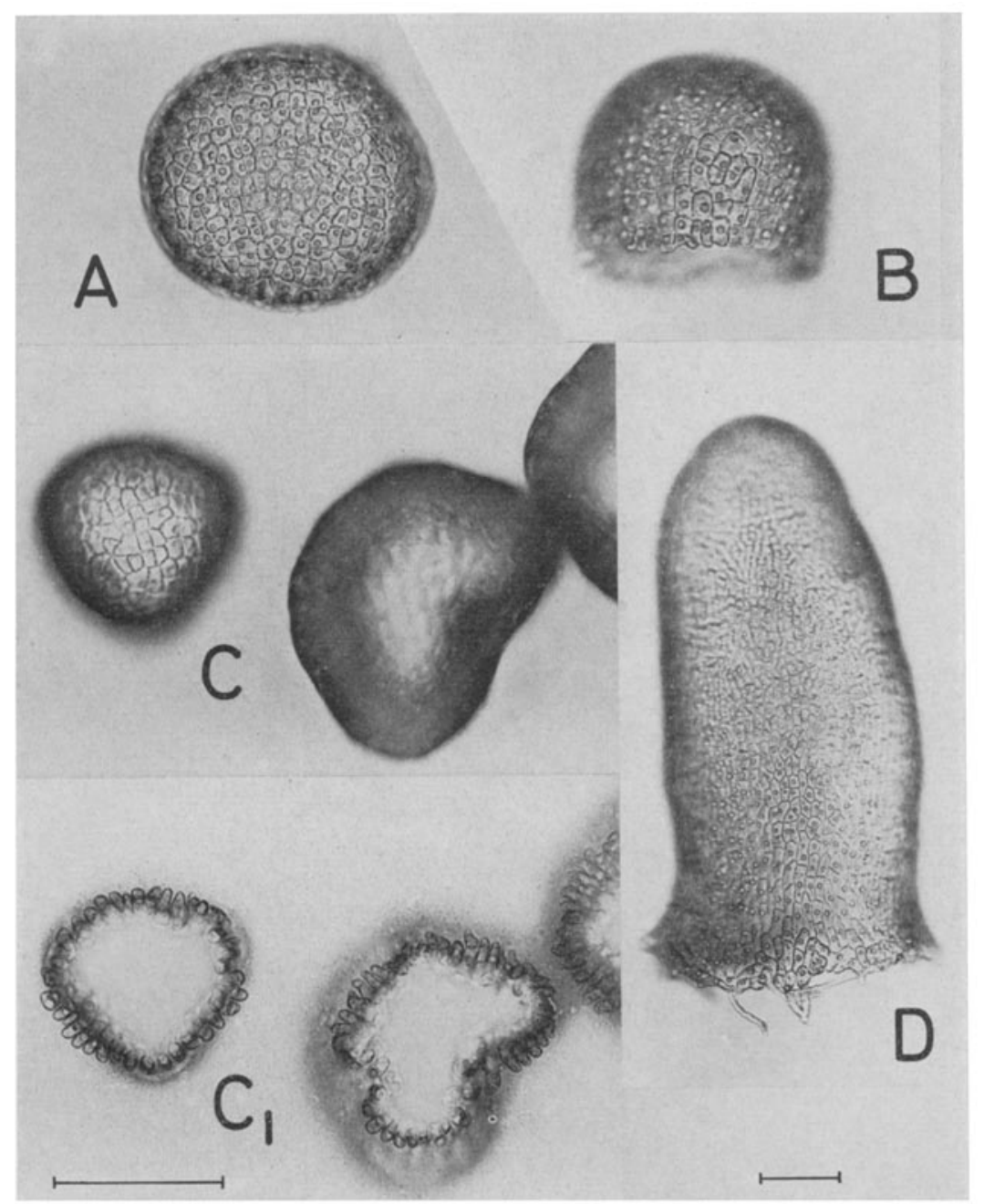

Fig. 4: Monostroma grevillei. Young gametophytes. A Seen from above. $B$ Side view. $C, C$ The same group grown on a cover slip, seen from above and below, respectively. $D$ Elongation into a sack-shaped stage. Scale length: $100 \mu \mathrm{m}$

\section{Gomontia polyrbiza}

Similarities of early developmental stages in both generations justify looking at Gomontia polyrbiza as a closely related form of Monostroma grevillei. Disk-formation of the gametophyte repeats the pattern shown in Monostroma (Fig. 5), but instead of producing sack-shaped vesicles, the cells give rise to short upright filaments united together to a cushion-like monoecious gametophyte. In free culture, the zygote develops 


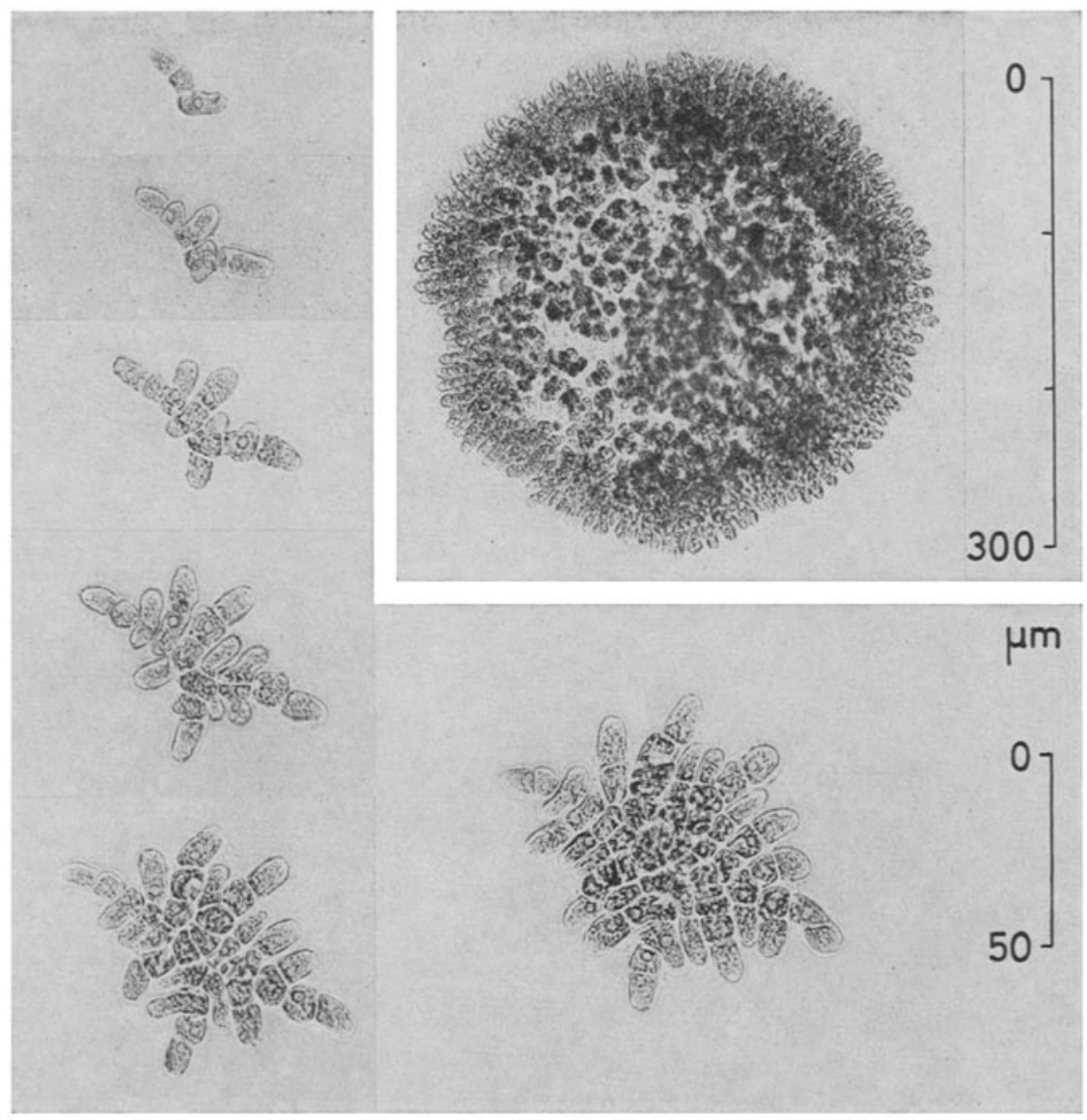

Fig. 5: Gomontia polyrbiza. Some stages of gametophyte development at daily intervals. Above right is a fertile gametophyte

in the same way as described in Monostroma (Fig. $6 \mathrm{~A}, \mathrm{~B}$ ); when germinating on the surface of mussel-shell, the typical polyrhizoidal sporophyte is produced (Fig. 6 D, E). At the surface of the culture medium intermediary habits may occur (Fig. $6 \mathrm{C}$ ).

\section{Acrosiphonia spinescens}

Though the gametophyte lacks any morphological similarity with the preceding forms, the early stages of sporophyte development are entirely identical to those of Monostroma; Figure 7 needs no further comment. In free culture, the stalk continues growth in length and may become tortuous (KoRNMANN 1965b). In the field, the sporophyte - known as "Codiolum petrocelidis" - lives endophytically in crusts of Petrocelis cruenta (Jónsson 1959). The alga, however, originally described under this 

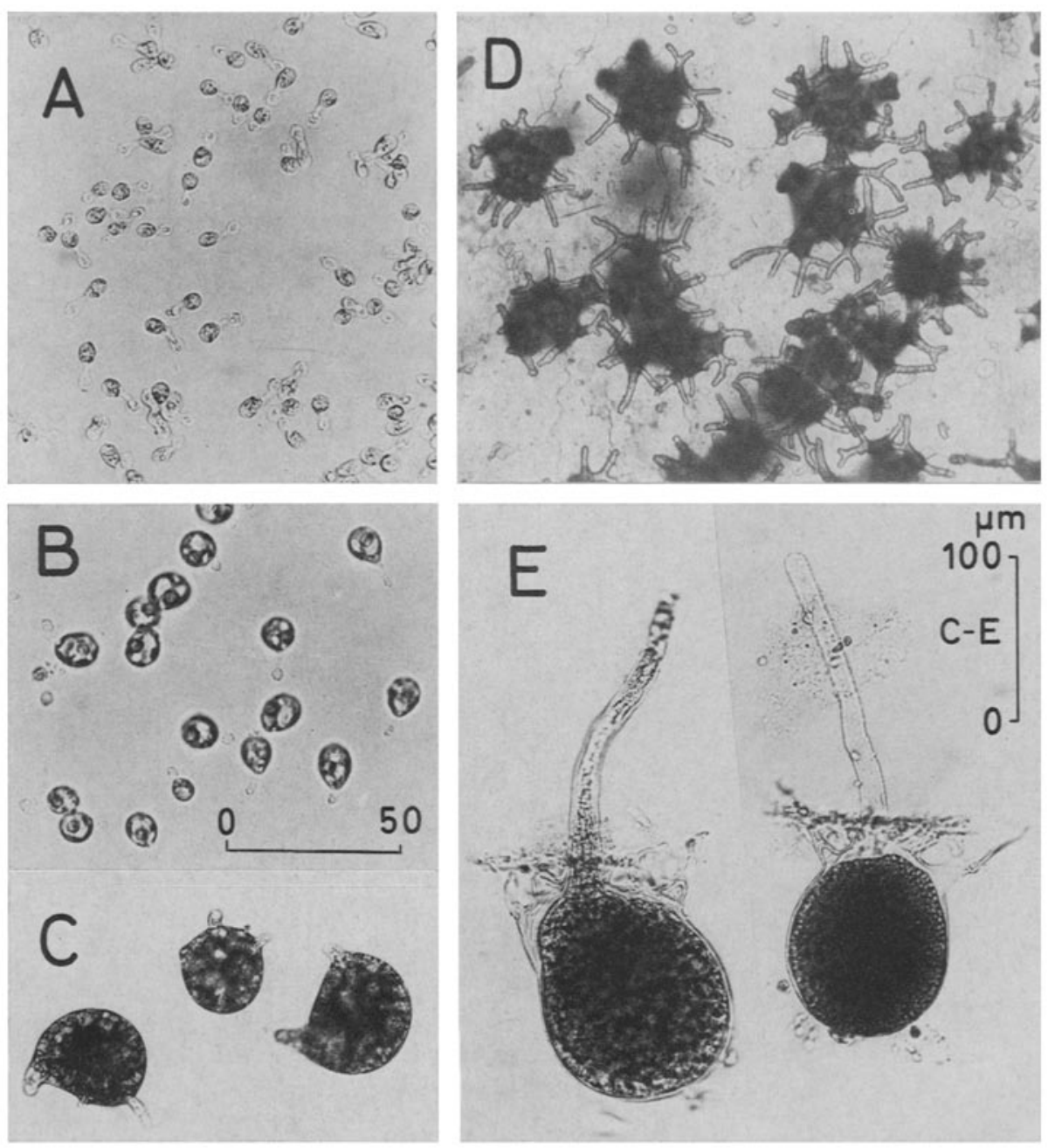

Fig. 6: Gomontia polyrhiza. Sporophytes. $A, B$ Grown on the bottom of a dish, one day and four days old, respectively. $C$ From the surface of the culture medium, 16 days old. $D$ Grown in mussel shell, seen from above, 15 days old. $E$ Mature sporophytes from mussel shells after decalcification, 10 weeks old. Same scale for $A-D$

name by KuckUck at Helgoland, is an endophyte in $P$. hennedyi, and has proved to be the sporophyte of Spongomorpha aernginosa. This sporophyte modifies into Chlorochytrium inclusum when living in Polyides rotundus (KorNMann 1961a). It has recently been confirmed by experimental work that "Codiolum petrocelidis" and "Chlorocbytrium inclusum" are non-specific entities; the relationships to their corresponding gametophytes must be elucidated by culture experiments (CHIHARA 1969, KornmanN 1972).

The habits of Acrosipbonia and Spongomorpha are similar to that of Cladophora, 

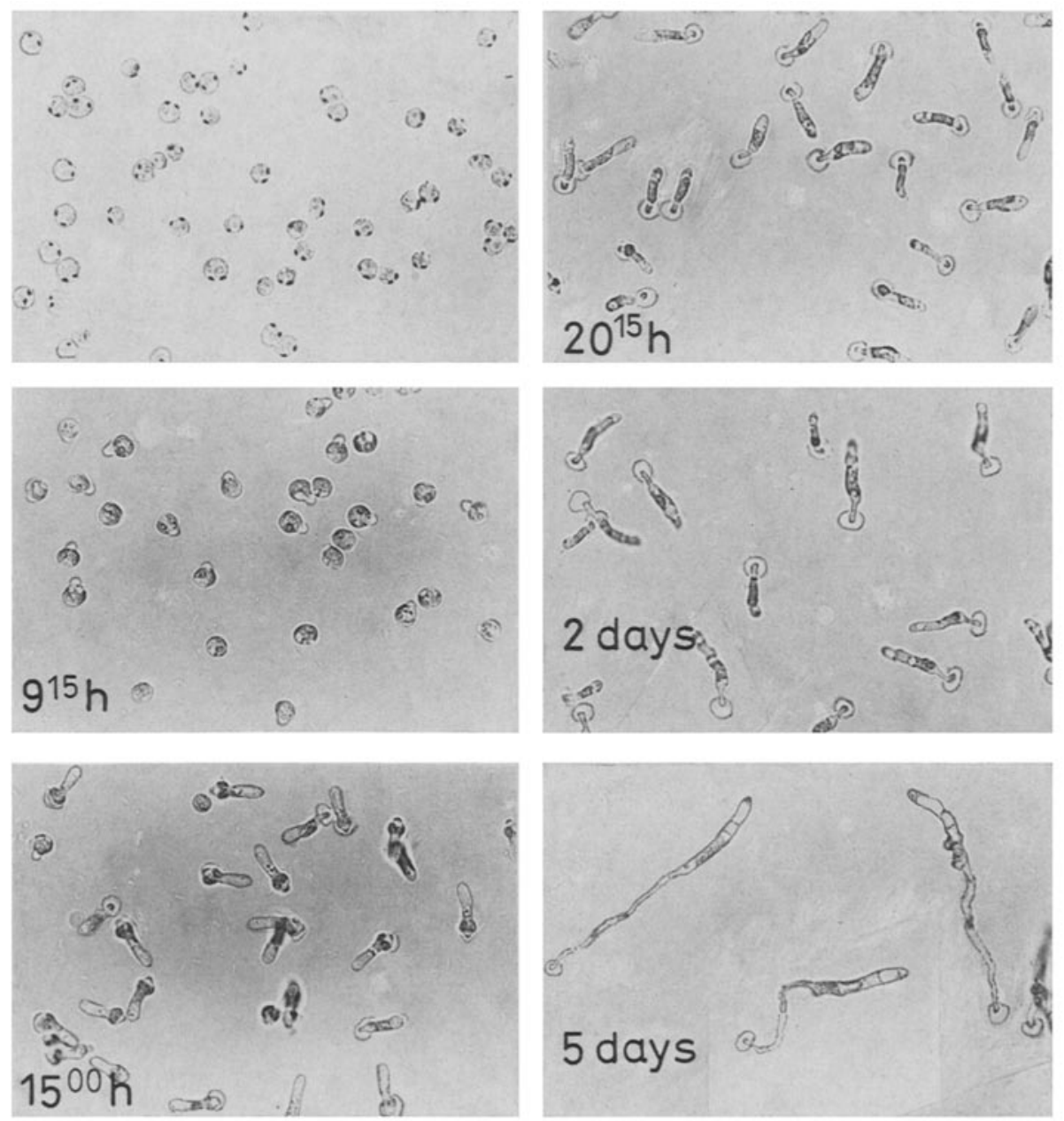

Fig. 7: Acrosiphonia spinescens. Sporophyte development up to an age of 5 days. Zygotes settled the afternoon before dates indicated

but there is a fundamental difference in growth pattern. In Acrosiphonia, lengthening is restricted to apical cells, and intercalary cells do not stretch after division as they do in Cladopbora (unpublished own observations) and Chaetomorpha (KoRnManN 1968, 1969). Constancy of general growth patterns and of specific peculiarities in the division of apical cells has already been shown (Kornmann 1965c, 1967, also summarized briefly in English, 1970).

In the classification of Round (1971), the Acrosiphoniales are placed in the subclass of Hemisiphoniideae together with Cladophorales and Sphaeropleales. There is no reason at all to approach Acrosiphonia to Cladophora since differences in biological features and chemistry of cell membranes speak urgently for their separation. 


\section{Urospora, Hormiscia}

Life cycles of all proven species show a unicellular sporophytic stage (except the monogenetic forms occurring here, as in the other groups under consideration). Unfortunately, details of the primary phase of sporophyte development have not yet been investigated (KornmanN 1961b, 1966b), and it has not been possible to fill this gap, as sexual filaments of Hormiscia are rarely found near Helgoland.

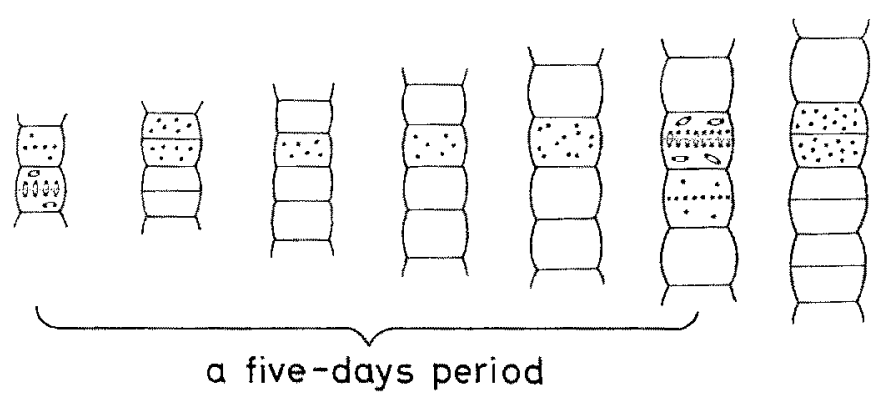

Fig. 8: Urospora wormskioldii. Scheme of intercalary growth, the number of nuclei reduced in order to point out the principle of their behaviour. (After KorNMANN 1970)

Den Hartog (1959) first created the family Codiolaceae to include forms of heteromorphic life cycle and posteriorly pointed zoospores. Intercalary growth and a most characteristic behaviour of nuclei during the five-day period of cell generation time add further peculiarities to the above-mentioned ones (Fig. 8). During celldivision, approximately half of the nuclei form an equatorial girdle, then simultaneous mitosis of all nuclei precedes cytokinesis. The day before the next cell-division, the number of nuclei is duplicated by simultaneous mitoses (KoRNMANN 1966a, also briefly reported in English 1970). PARKE \& DrXoN (1968) include Urospora in the Acrosiphoniales, but considering all these distinct features, the creation of the order Codiolales (Kornmann 1965a) seems justified.

\section{Ulotbrix}

Life cycles of all marine sexual species under investigation include a typical Codiolum-stage. As to Ulotbrix zonata, a freshwater alga, the heteromorphous life cycle has been conclusively proved by Dodel as far back as 1876 . Sporophyte development of $U$. subflaccida shows the characteristic stages demonstrated in Acrosipbonia and Monostroma (Fig. 9, photos of three and four-day old cultures containing some filamentous germinations from zoospores).

The order Ulotrichales, varying widely in the concept of authors, is restricted here to the genus Ulotbrix. Recently, STEWART et al. (1972) have shown by comparative cytological studies of some "species" of Ulotbrix and Uronema, that the genus Ulotbrix is a heterogeneous assemblage. $U$, zonata differs significantly from the 

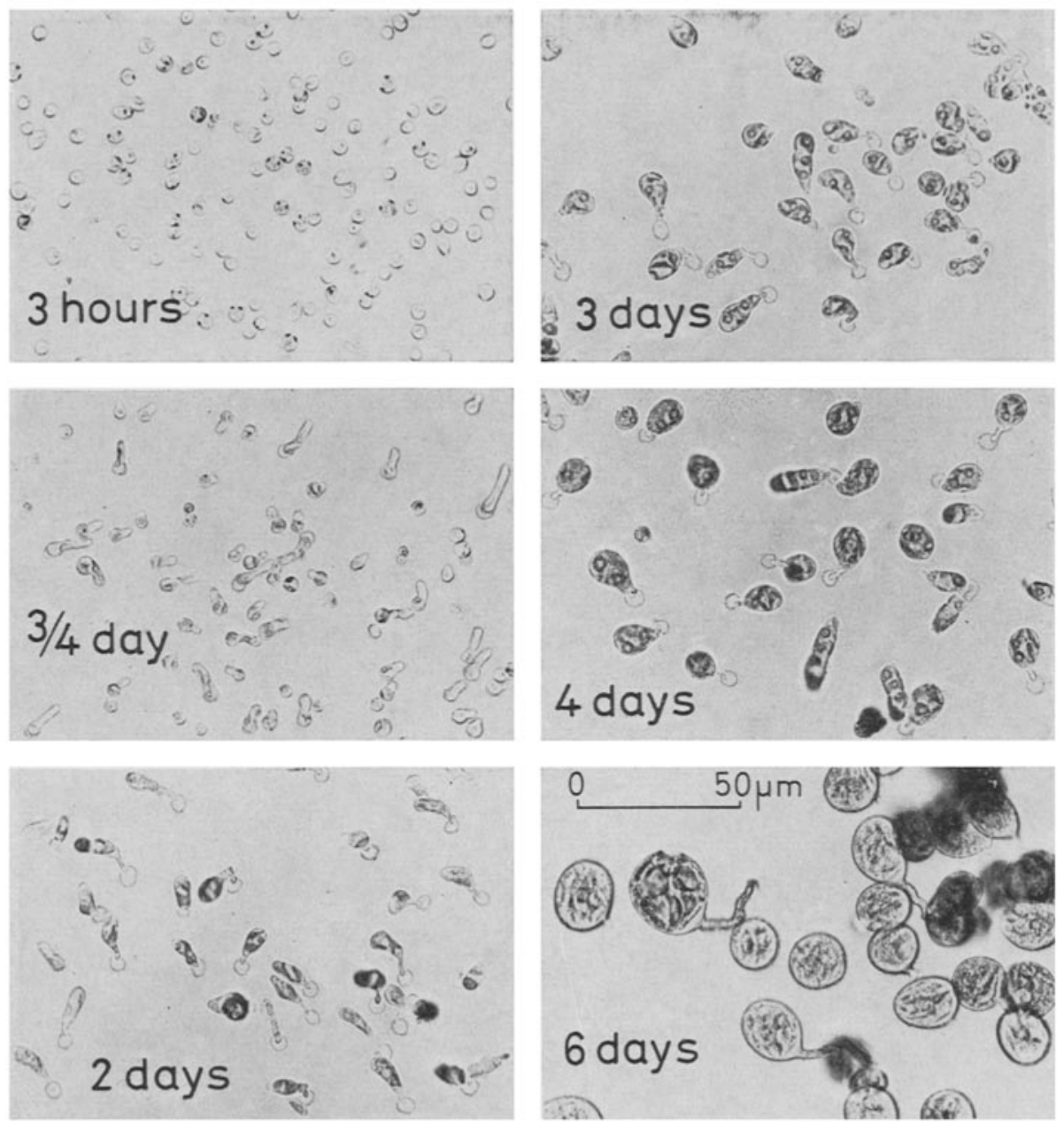

Fig. 9: Ulotbrix subflaccida. Sporophyte development up to an age of 6 days

other species under investigation, whose affinities lie with the Chaetophoraceae rather than with the Ulotrichaceae.

\section{CONCLUSIONS}

The basic reason for the establishment of the new class Codiolophyceae to embrace the Ulotrichales, Monostromatales, Codiolales and Acrosiphoniales is the fact of the heteromorphic life cycle including a Codiolum-stage. Detailed observation of germinating zygotes has shown a most specific pattern of sporophyte development. The differentiation of a germinating cell into basal disk, stalk and club does not occur in 
the ontogeny of any other group of green algae. Therefore it may indicate a high degree of phylogenetic relationship. In this way these orders of green algae share a common criterion, the like of which is lacking in the remaining groups of Chlorophyceae. Moreover, the members of the Codiolophyceae agree with regard to their ecological type: they all are representatives of the Eclipsiophyceae, whose gametophytes occur in spring, whereas sporophytes become mature during winter-time.

\section{SUMMARY}

1. Representatives of the genera Ulotbrix, Monostroma, Gomontia, Hormiscia, Acrosiphonia and Spongomorpha, though widely differing in morphological characters of their gametophytes, agree in the presence and similar development of a unicellular sporophytic Codiolum-stage.

2. These genera have been united into a new class, Codiolophyceae, to indicate a high degree of phylogenetic relationship, thus eliminating at the same time the present unsatisfactory classification into 3-4 different orders of the Chlorophyta.

\section{LITERATURE CITED}

Bliding, C., 1968. A critical survey of European taxa in Ulvales, II. Ulva, Ulvaria, Monostroma, Kornmannia. Bot. Notiser 121, 535-629.

ChrHara, M., 1969. Culture study of Chlorocbytrimm inclusum from the northeast Pacific. Phycologia 8, 127-133.

DoDel, A, 1876. Ulotbrix zonata, thre geschlechtliche und ungeschlechtliche Fortptlanzung, ein Beitrag zur Kenntnis der unteren Grenze des pflanzlichen Sexuallebens. Jb. wiss. Bot. 10, $417-550$.

HARTOG, C.DEN, 1959. The epilithic algal communities occurring along the coast of the Netherlands. Wentia 1, 1-241.

Jónsson, S., 1959. L'existence de lalternance hétéromorphe de générations entre l'Acrosipbonia spinescens KJELLM, et le Codiolum petrocelidis Kuck. C. r. hebd. Séanc. Acad. Sci., Paris 248, 322-323.

Kornmann, P., 1961a. Uber Spongomorpha lanosa und ihre Sporophytenformen. Helgoländer wiss. Meeresunters. 7, 195-205.

- 1961b. Uber Codiolum und Urospora. Helgoländer wiss. Meeresunters. 8, 42-57.

- 1962. Die Entwicklung von Monostroma grevillei. Helgoländer wiss. Meeresunters. 8, 195-202.

- 1963. Die Ulotrichales, neu geordnet auf der Grundlage entwicklungsgeschichtlicher Befunde. Phycologia 3, 60-68.

- 1964. Uber Monostroma bullosm (Roth) Thuret und M. oxyspermum (Kütz.) DotY. Helgoländer wiss, Meeresunters. 11, 13-21.

- 1965a. Ontogenie und Lebenszyklus der Ulotrichales in phylogenetischer Sicht. Phycologia 4, 163-172.

- 1965b. Was ist Acrosiphonia arcta? Helgoländer wiss. Meeresunters. 12, 40-51.

- 1965c. Zur Analyse des Wadstums und des Aufbaus von Acrosiphonia. Helgoländer wiss. Meeresunters. 12, 219-238.

- 1966a. Wachstum und Zellteilung bei Urospora. Helgoländer wiss. Meeresunters. 13, 73-83.

- 1966b. Hormiscia neu definiert. Helgoländer wiss. Meeresunters. 13, 408-425. 
- 1967. Wachstum und Aufbau von Spongomorpha aeruginosa (Chlorophyta, Acrosiphoniales). Blumea 15, 9-16.

- 1968. Das Wachstum einer Chaetomorpha-Art von List/Sylt. Helgoländer wiss. Meeresunters, 18, 194-207.

- 1969. Gesetzmäßigkeiten des Wachstums und der Entwidklung von Chaetomorpha darwinii (Chlorophyta, Cladophorales). Helgoländer wiss. Meeresunters. 19, 335-354.

- 1970. Advances in marine phycology on the basis of cultivation. Helgoländer wiss. Meeresunters. 20, 39-61.

- 1972. Les sporophytes vivant en endophyte de quelques Acrosiphoniacées et leur rapports biologiques et taxonomiques. Mém. Soc. bot. Fr, 1972, 75-86.

- \& Sahling, P. H., 1962. Zur Taxonomie und Entwidklung der Monostroma-Arten von Helgoland. Helgoländer wiss. Meeresunters. 8, 302-320.

Parke, M. \& Dixon, P. S., 1968. Check-list of British marine algae - second revision. J. mar. biol. Ass. U.K. 48, 783-832.

Round, F. E., 1971. The taxonomy of the Chlorophyta. II. Br. phycol. Bull. 6, 235-264.

StewarT, K. D., Mattox, K. R. \& Fioyd, G. L., 1972. Comparative cytology of the genus Ulothrix with special emphasis on $U$. zonata. J. Phycol. 8 (Suppl.), 8.

TATEWAKI, M., 1972. Life history and systematics in Monostroma. In: Contributions to the systematics of benthic matine algae of the North Pacific. Ed. by J. A. AвbотT \& M. KuROGr. Jap. Soc. of Phycology, Kobe, 280 pp.

Author's address: Dr. Dr. h. c. P. Kornmann

Biologische Anstalt Helgoland

Meeresstation

2192 Helgoland

Germany (FRG) 